\title{
Sex- and Age-Related Estrogen Signaling Alteration in Inflammatory Bowel Diseases: Modulatory Role of Estrogen Receptors
}

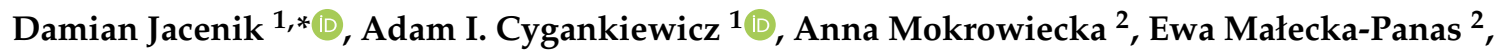 \\ Jakub Fichna ${ }^{3}$ and Wanda M. Krajewska ${ }^{1, *}$ \\ 1 Department of Cytobiochemistry, Faculty of Biology and Environmental Protection, University of Lodz, \\ Pomorska St. 141/143, 90-236 Lodz, Poland \\ 2 Department of Digestive Tract Diseases, Faculty of Medicine, Medical University of Lodz, \\ Stefana Kopcinskiego St. 22, 90-001 Lodz, Poland \\ 3 Department of Biochemistry, Faculty of Medicine, Medical University of Lodz, Mazowiecka St. 6/8, \\ 92-215 Lodz, Poland \\ * Correspondence: damian.jacenik@biol.uni.lodz.pl (D.J.); wanda.krajewska@biol.uni.lodz.pl (W.M.K.); \\ Tel.: +48-426-355-299 (D.J.); +48-426-354-487 (W.M.K.)
}

Received: 3 June 2019; Accepted: 26 June 2019; Published: 28 June 2019

\begin{abstract}
The pathogenesis of inflammatory bowel diseases (IBD) seems to be associated with alterations of immunoregulation. Several lines of evidence suggest that estrogens play a role in the modulation of immune responses and may be related to the etiology of IBD. The purpose of this work was to examine the involvement of G protein-coupled estrogen receptor (GPER), estrogen receptor $\alpha(E R \alpha)$, estrogen receptor $\beta(E R \beta)$ and $E R \alpha$ spliced variants $E R \alpha 36$ and $E R \alpha 46$ in Crohn's disease (CD) and ulcerative colitis (UC). The studied group included 73 patients with IBD and 31 sex and age-related controls. No differences in serum levels of $17 \beta$-estradiol nor of CYP1A1 and SULT1E1 enzymes involved in estrogen catabolism were stated. The expression pattern of estrogen receptors in tissue samples was quantified using real-time PCR and Western blotting. Statistically significant up-regulation of GPER and ER $\alpha$ in both CD and UC as well as down-regulation of ER $\beta$ in CD patients was found. However, differences in the expression of estrogen receptors in $C D$ and UC have been identified, depending on the sex and age of patients. In men, up-regulation of GPER, ER $\alpha$ and ER $\alpha 46$ expression was shown in CD and UC patients. In women under 50 years of age, GPER protein level increased in UC whereas ER $\beta$ expression tended to decrease in CD and UC patients. In turn, in women over 50 the protein level of ER $\alpha$ increased in UC while ER $\beta$ expression decreased in CD patients. Dysregulation of estrogen receptors in the intestinal mucosa of patients with CD and UC indicates that estrogen signaling may play a role in the local immune response and maintain epithelial homeostasis in a gender- and age-dependent manner.
\end{abstract}

Keywords: inflammatory bowel diseases; Crohn's disease; ulcerative colitis; estrogen receptors; GPER; ER $\alpha ; E R \beta ; E R \alpha 36 ; E R \alpha 46$

\section{Introduction}

Crohn's disease (CD) and ulcerative colitis (UC), the most commonly diagnosed types of inflammatory bowel diseases (IBD), are complex, immunologically mediated diseases of the gastrointestinal tract. Despite the differences between CD and UC pathology several phenomena such as dysregulation of the immune response, the gut microbiome, as well as genetic and environmental factors seem to be crucial in IBD pathogenesis [1-3]. Males are more likely to develop UC, whereas 
females are more likely to develop $\mathrm{CD}[4,5]$. However, the molecular mechanisms for this bias remains unclear.

Estrogens play a complex role in the pathophysiology and accumulated data suggest the impact of estrogens on IBD [6-10]. There is evidence showing a higher prevalence of both IBD types with a relative risk of 1.65 for $\mathrm{CD}$ and 1.35 for UC in women [11]. A number of epidemiological studies have shown that exogenous hormone supplementation such as oral contraceptives $(\mathrm{OC})$ or hormone replacement therapy (HRT) in postmenopausal women is associated with the occurrence of IBD. A meta-analysis by Ortizo et al. [12] indicated that OC users are characterized by a $24 \%$ and $30 \%$ higher risk for developing CD and UC, respectively. The positive relationship between OC use and risk of developing CD was noted in a large prospective cohort study [6]. Additionally, OC administration, and particularly the combination type, in long-term users was related with a higher possibility for CD-related surgery [7]. An association between HRT and increased risk of UC was also documented. The risk of UC appeared to increase with longer duration of hormone use. The contribution of HRT to $\mathrm{CD}$ is controversial. It has been suggested that HRT has no effect on Crohn's disease [8]. On the other hand, in case-control analysis a positive relationship between HRT and CD development was found [9]. In contrast, the anti-inflammatory effects of estrogen supplementation in IBD has been demonstrated. Kane et al. [10] documented a dose-dependent protective property of HRT on disease severity in IBD.

Estrogen activity is the result of interaction with the relevant receptors and triggering estrogen-dependent effects on signaling pathways. In the classic pathway, ligand binds to the nuclear estrogen receptors (ER $\alpha$ and $E R \beta)$, which leads to changes in receptor conformation, dissociation of heat shock proteins (HSPs) and homo- or hetero-dimerization. Dimers are translocated to the cell nucleus, where by direct interaction with specific DNA sequences or indirectly via transcription factors, they regulate the expression of target genes on the genomic/long-term pathway. In addition to the classical genomic effects, the short-term/non-genomic action of estrogens is mediated by membrane-associated G protein-coupled estrogen receptor (GPER, formerly GPR30). Ligand-dependent activation of GPER leads to rapid activation of several proteins involved in signal transduction resulting in changes at the transcriptional level [13]. It is noteworthy, that there are also alternatively spliced variants of wild type $\mathrm{ER} \alpha$, i.e., $\mathrm{ER} \alpha 36$ and $\mathrm{ER} \alpha 46$, which are able to mediate both the non-genomic and genomic action of estrogens $[13,14]$. A growing body of evidence shows that estrogen signaling is a complex network, that is regulated by cross-talk between estrogen receptors, dependent on the tissue expression pattern of estrogen receptors $[13,15]$.

The growing body of literature data emphasize the relationship between estrogen signaling and inflammation [16-18]. Based on epidemiological and experimental data, it is suggested that estrogen receptors $\alpha$ and $\beta$ are important mediators of intestine inflammation. Although ER $\beta$ plays a minor role in mediating action in classical estrogen target tissues, it appears that this receptor plays an important role in the colon. Notably, ER $\beta$ expression was decreased in the colonic mucosa of IBD patients with active disease $[19,20]$. However, it has been proven that both nuclear estrogen receptors modulate epithelial barrier function. The findings of Goodman et al. [21] suggest that differences in ER $\alpha / E R \beta$ signaling ratio affect colitis in males and females. In addition, our recent studies have shown that GPER expression is associated with colon inflammation in murine model of CD, and ligands acting through the appropriate estrogen receptors affect colitis not only at the macroscopic and microscopic levels, but also appear to be important regulators of signal transmission and immunomodulatory genes expression in the colon [22].

In our study, we investigated the involvement, not only of nuclear estrogen receptors ER $\alpha$ and $\mathrm{ER} \beta$, but also $\mathrm{G}$ protein-coupled estrogen receptor (GPER) and truncated forms of ER $\alpha$, i.e., ER $\alpha 36$ and ER $\alpha 46$, in Crohn's disease and ulcerative colitis and their relationship with gender and age. Better understanding of the role of estrogens receptors may advance our knowledge and the therapeutics or prevention strategies for IBD. 


\section{Results}

\subsection{Patients Characteristics}

A total of one hundred and four patients hospitalized from 2011 to 2017 in the Department of Digestive Tract Disease, Faculty of Medicine at the Medical University of Lodz, Poland were enrolled for this study. Serum and forceps endoscopic biopsies of colon were collected from 31 CD patients (19 men, seven women under 50 and five women over 50 years old), 42 UC patients (24 men, 12 women under 50 and six women over 50 years old) and 31 unrelated controls (12 men, nine women under 50 and ten women over 50 years old). All blood parameters such as white blood cells, neutrophils, lymphocytes, monocytes, eosinophils, basophils, red blood cell counts and hemoglobin, sodium and potassium levels were in the normal range. However, the level of C-reactive protein (CRP), which is a biomarker of inflammation, was more than 30-fold and 33-fold higher in patients with CD and UC, respectively, compared to the control group (Table 1). In IBD patients in relation to the control group, a statistically significant increase of mRNA level for interleukin-6 (IL-6) that acts as pro-inflammatory cytokine was also observed (Table 2). As shown in Table 2, the statistically significant up-regulation at the mRNA level of one of the most highly expressed cytokines in human chronic inflammatory diseases that is involved in immune cell trafficking, i.e., CCL18 was stated in UC but not in CD patients compared to controls. Similarly, higher, but not statistically significant interleukin-10 (IL-10) transcript level in patients with UC but not with CD compared to the control group was noted. Our analysis demonstrated no changes in tumor necrosis factor- $\alpha$ (TNF- $\alpha)$ and nuclear factor kappa-light-chain-enhancer of activated B cells (NFkB) mRNA level in colon samples obtained from IBD patients (Table 2). There were no differences in the parameters tested in relation to the sex and age of patients.

Table 1. Laboratory findings of control subjects and IBD patients enrolled in the study.

\begin{tabular}{cccc}
\hline Parameters (unit) & Control & CD & UC \\
\hline White blood cell (G/L) & $8.6 \pm 0.2$ & $9.1 \pm 1.1$ & $8.4 \pm 0.8$ \\
Neutrophil (G/L) & $5.9 \pm 0.2$ & $6.9 \pm 1.1$ & $5.4 \pm 0.6$ \\
Lymphocyte (G/L) & $1.8 \pm 0.3$ & $1.4 \pm 0.1$ & $1.8 \pm 0.2$ \\
Monocyte (G/L) & $0.8 \pm 0.6$ & $1.0 \pm 0.4$ & $0.7 \pm 0.1$ \\
Eosinophil (G/L) & $0.18 \pm 0.01$ & $0.14 \pm 0.02$ & $0.14 \pm 0.03$ \\
Basophil (G/L) & $0.05 \pm 0.01$ & $0.03 \pm 0.01$ & $0.05 \pm 0.02$ \\
Red blood cell (T/L) & $4.4 \pm 0.3$ & $4.3 \pm 0.1$ & $4.3 \pm 0.1$ \\
Hemoglobin (g/dL) & $13.9 \pm 0.4$ & $12.7 \pm 0.3$ & $12.7 \pm 0.3$ \\
Sodium (mmol/dL) & $139.6 \pm 4.0$ & $137.6 \pm 0.5$ & $137.0 \pm 1.5$ \\
Potassium (mmol/dL) & $4.3 \pm 0.2$ & $4.0 \pm 0.1$ & $4.0 \pm 0.1$ \\
C-reactive protein (CRP; mg/dL) & $1.1 \pm 0.2$ & $31.8 \pm 9.1 * *$ & $35.4 \pm 11.3 * * *$ \\
\hline
\end{tabular}

Values presented as a means $\pm \mathrm{SEM} ;{ }^{* *} P<0.01,{ }^{* * *} P<0.001$ vs. control.

Table 2. Relative mRNA expression level of selected biomarkers of inflammation in control subjects and IBD patients enrolled in the study.

\begin{tabular}{cccc}
\hline Inflammation Biomarkers & Control & CD & UC \\
\hline Interleukin-6 (IL-6) & $4.11 \pm 1.25$ & $30.98 \pm 13.18^{* *}$ & $50.33 \pm 21.14^{*}$ \\
Interleukin-10 (IL-10) & $1.57 \pm 0.53$ & $2.21 \pm 0.78$ & $6.00 \pm 2.83$ \\
C-C chemokine motif ligand 18 (CCL18) & $1.08 \pm 0.35$ & $4.94 \pm 1.64$ & $2.16 \pm 0.36^{*}$ \\
Tumor necrosis factor- $\alpha$ (TNF- $\alpha$ ) & $4.64 \pm 1.01$ & $5.62 \pm 1.40$ & $5.89 \pm 1.76$ \\
Nuclear factor kappa-light-chain-enhancer of & $102.10 \pm 11.21$ & $138.10 \pm 34.29$ & $116.90 \pm 29.76$ \\
activated B cells (NFKB) & & & \\
\hline
\end{tabular}

Values presented as a means $\pm \mathrm{SEM} ;{ }^{*} P<0.05,{ }^{* *} P<0.01$ vs. control. 


\subsection{7ק-Estradiol, CYP1A1 and SULT1E1 Levels in Serum of IBD Patients}

The serum level of $17 \beta$-estradiol in males and females under and over the age of 50 years with IBD was found to be in the normal range. In the case of $C D$, the values were $51.74 \pm 6.24$ for men, $94.73 \pm 22.58$ for women under 50 years and $29.50 \pm 3.75$ for women over 50 years and in the case of UC $40.84 \pm 3.69$ for men, $91.63 \pm 26.15$ for women under 50 years and $23.89 \pm 0.73$ for women over 50 years (Figure 1a). As shown in Figure 1b, no differences were observed in the serum level of CYP1A1 (cytochrome P450 family 1 subfamily A member 1) for men and women under and over the age of 50 years with CD and UC compared to the control group. Similarly, no changes in the SULT1E1 (sulfotransferase family 1E member 1) serum level were found in the studied IBD forms in both men and women regardless of age (Figure 1c).
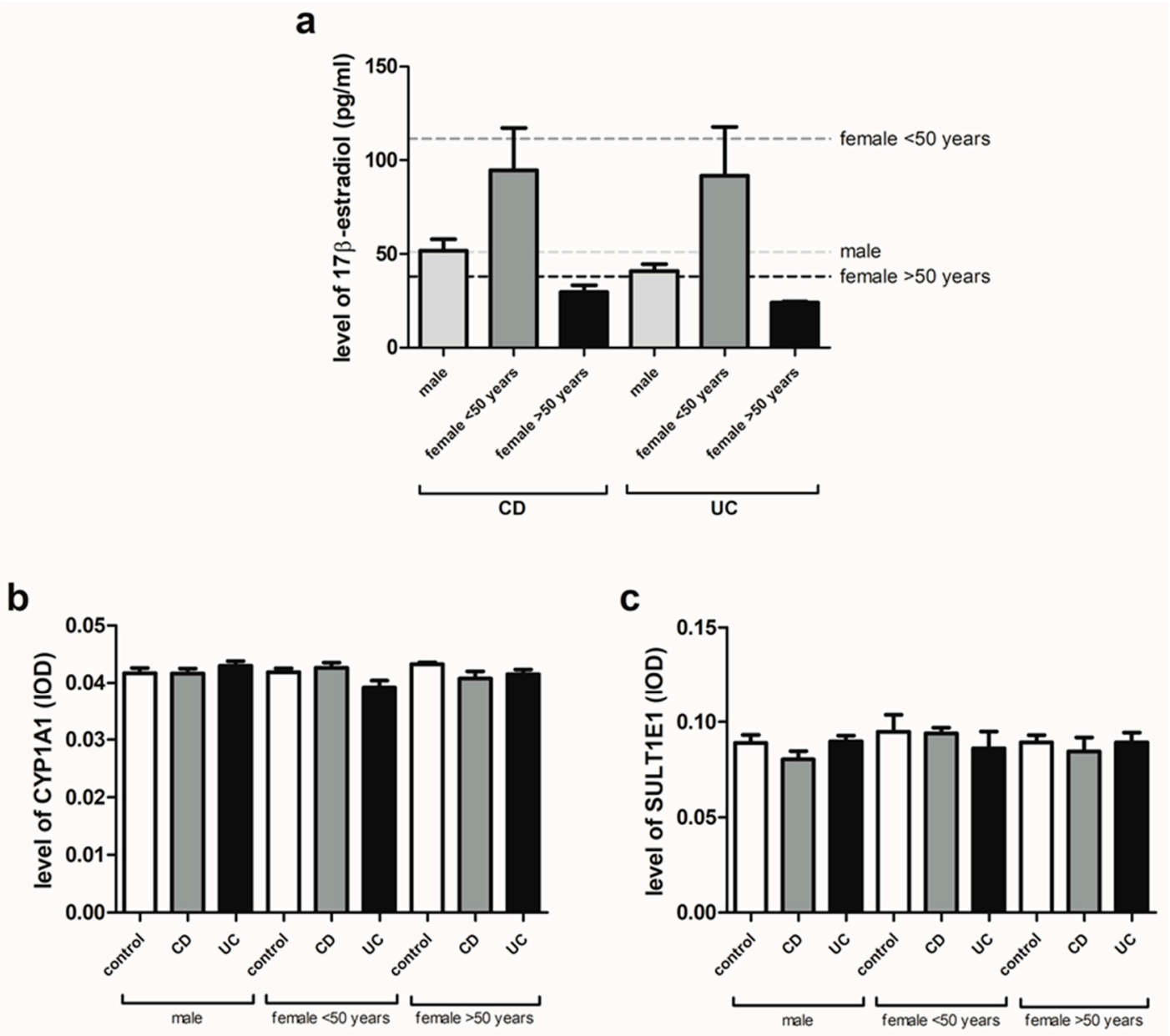

Figure 1. Serum 17 $\beta$-estradiol (a), CYP1A1 (b) and SULT1E1 (c) levels in CD and UC patients and related controls: males (control, $n=12 ; \mathrm{CD}, n=19 ; \mathrm{UC}, n=24$ ), females under the age of 50 years (control, $n=9 ; \mathrm{CD}, n=7 ; \mathrm{UC}, n=12$ ) and females over the age of 50 years (control, $n=10 ; \mathrm{CD}, n=5$; $\mathrm{UC}, n=6)$. Dotted lines represent reference values. Values are means $\pm \mathrm{SEM}$.

\subsection{Estrogen Receptors Expression in IBD Patients}

In colon samples obtained from patients with IBD, regardless of gender and age, despite the lack of statistically significant differences in GPER expression at the mRNA level up-regulation of the GPER protein level was demonstrated in both CD $(P=0.012)$ and UC $(P=0.019)$ in relation to the control group (Figure $2 \mathrm{a}, \mathrm{b}$ ). For $\mathrm{ER} \alpha$, a statistically significant increase in expression was revealed both at the level of mRNA and protein in $\mathrm{CD}(P=0.004$ and $P=0.028$, respectively $)$ and UC patients $(P=0.021$ and $P<0.0001$, respectively) compared to the control group (Figure $2 \mathrm{c}, \mathrm{d}$ ). In the case of ER $\beta$ expression 
analysis, a lower mRNA level and statistically significant $(P=0.043)$ decrease of ER $\beta$ protein level were observed in patients with $C D$ (Figure 2e,f). No differences were found in ER $\beta$ mRNA and protein expression in patients with $\mathrm{UC}(P=0.167$ and $P=0.441$, respectively) in relation to the control group.

Estrogen receptor analysis was also performed in an independent cohort using the dataset provided by Global Expression Omnibus (GEO; accession number: GSE6731). Colon samples from CD patients were characterized by statistically significant up-regulation of GPER $(P=0.045)$ at the mRNA level corresponding to the control group (Figure 3a). As shown in Figure $3 b$, in both $C D(P=0.018)$ and UC $(P=0.028)$ patients higher statistically significant mRNA level of ER $\alpha$ was revealed. No statistically significant differences in the case of ER $\beta$ mRNA analysis were observed in colon samples from IBD patients in comparison to the control group (Figure 3c).

a

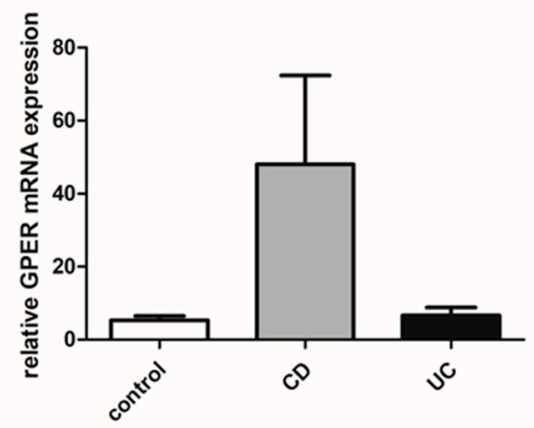

C

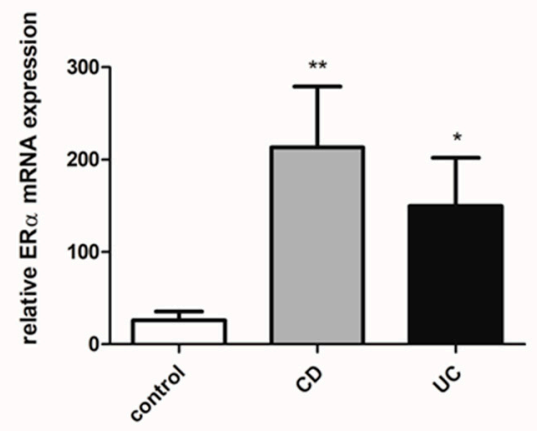

e

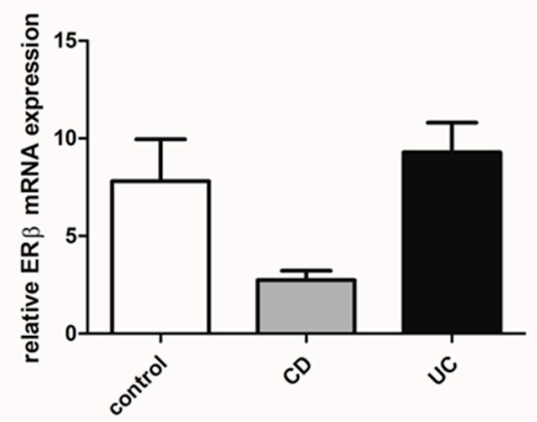

b

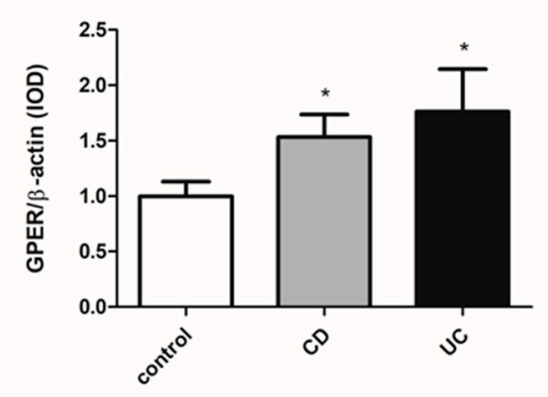

d

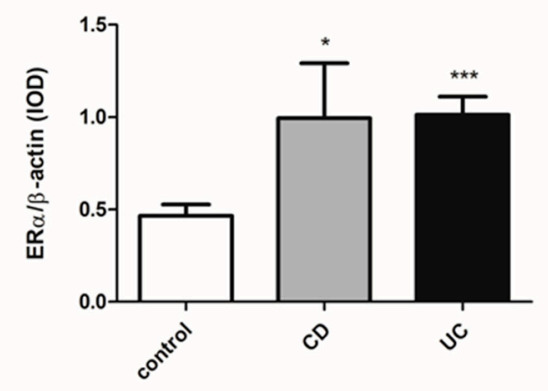

$\mathbf{f}$

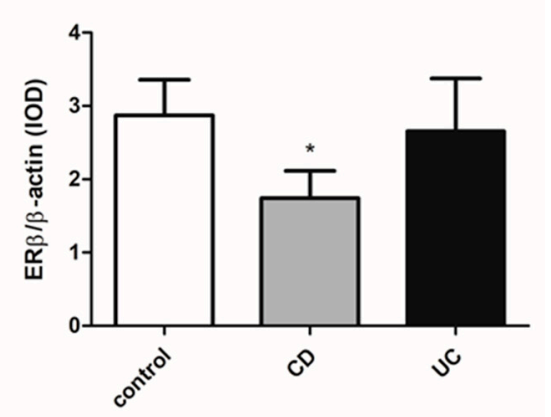

Figure 2. Expression of GPER (a,b), $\operatorname{ER} \alpha(\mathbf{c}, \mathbf{d})$ and $\operatorname{ER} \beta(\mathbf{e}, \mathbf{f})$ at the mRNA $(\mathbf{a}, \mathbf{c}, \mathbf{e})$ and protein level $(\mathbf{b}, \mathbf{d}, \mathbf{f})$ in CD and UC patients and the control group regardless of sex and age (control, $n=31 ; \mathrm{CD}$, $n=31 ; \mathrm{UC}, n=42)$. Values are means $\pm \mathrm{SEM} ;{ }^{*} P<0.05,{ }^{* *} P<0.01, * * * P<0.001$ vs. control. 

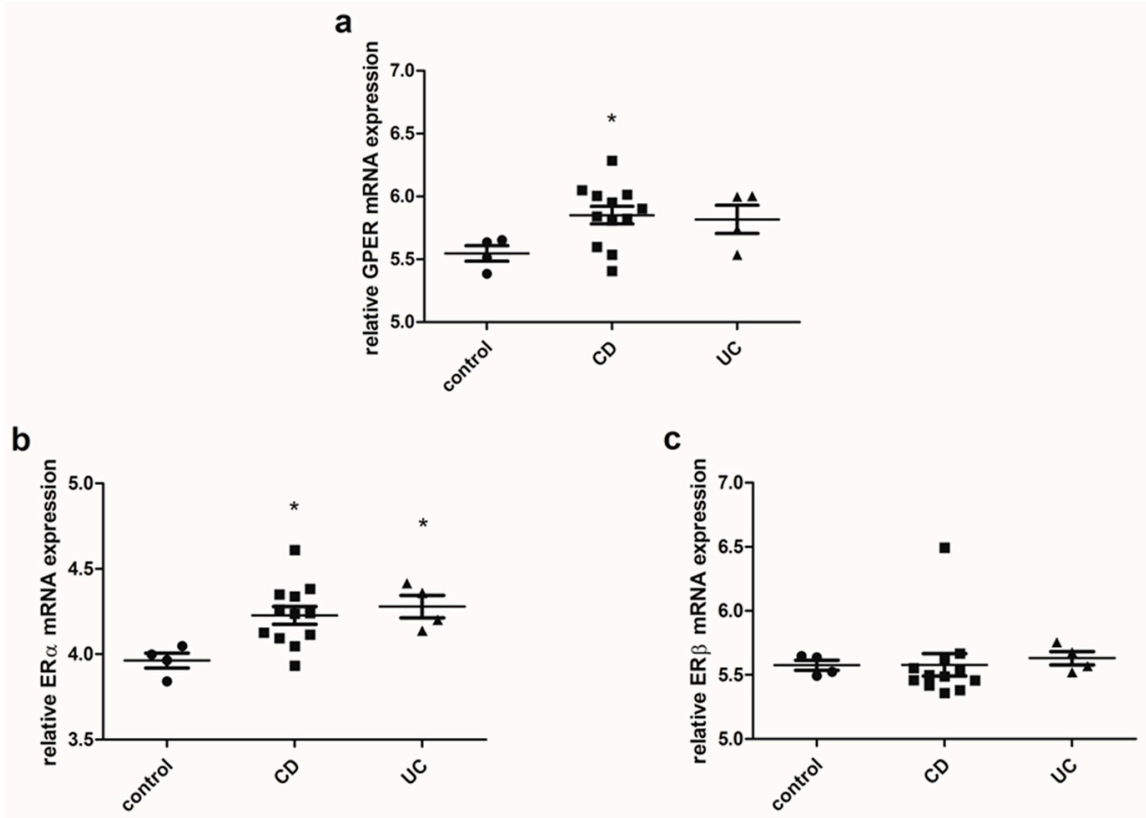

Figure 3. Expression of GPER (a), ER $\alpha(\mathbf{b})$ and $\operatorname{ER} \beta(\mathbf{c})$ at the mRNA level in CD and UC patients and the control group regardless of sex and age (control, $n=4$; CD, $n=12$; UC, $n=4$ ). Values are means \pm SEM; ${ }^{*} P<0.05$ vs. control.

\subsection{Estrogen Receptors Expression in Men with IBD}

In men examined in this study, the expression pattern of estrogen receptors substantially resembles that observed in IBD patients without considering sex and age. A statistically significant increase of GPER mRNA expression in men with $C D(P=0.020)$ compared to the control group was observed (Figure 4a). In contrast, in colon samples obtained from men with UC, the absence of GPER mRNA expression changes was shown. Interestingly, a statistically significant up-regulation of GPER protein level in both IBD types, i.e., CD and UC ( $P=0.006$ and $P=0.008$, respectively) was demonstrated (Figure $4 b$ ). Higher, statistically significant expression at both the ER $\alpha$ transcript and protein levels was also demonstrated in colon samples taken from male patients with $C D$ and UC $(P=0.005$ and $P=0.006$ for mRNA, respectively; $P=0.006$ and $P=0.010$ for protein, respectively) (Figure $4 \mathrm{c}, \mathrm{d}$ ). Despite the absence of statistically significant disturbances of the relative ER $\beta$ mRNA and protein level, a downward trend can be observed in male CD patients (Figure 4e,f).

a

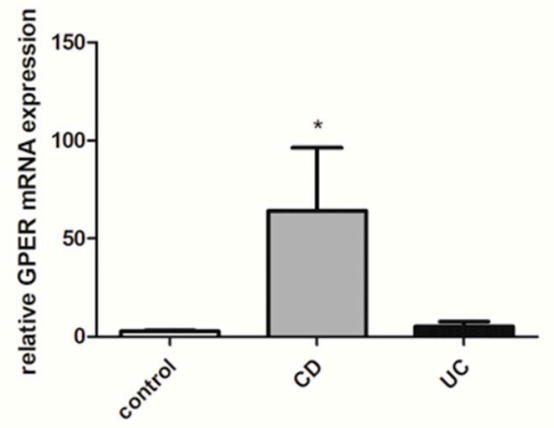

b

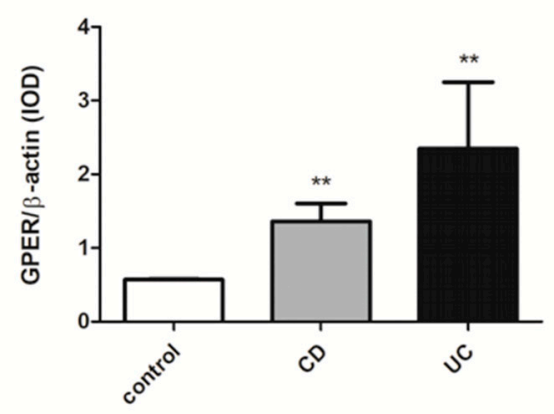

Figure 4. Cont. 
C

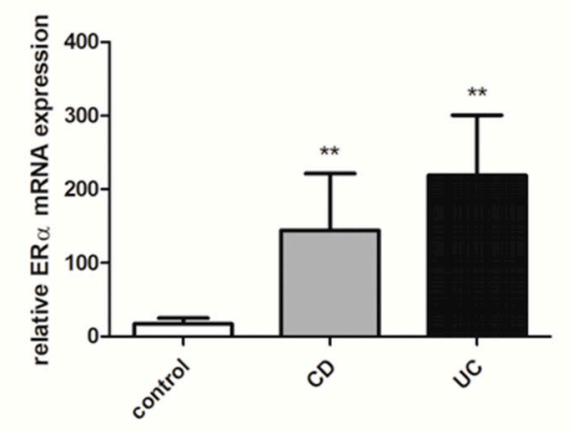

e

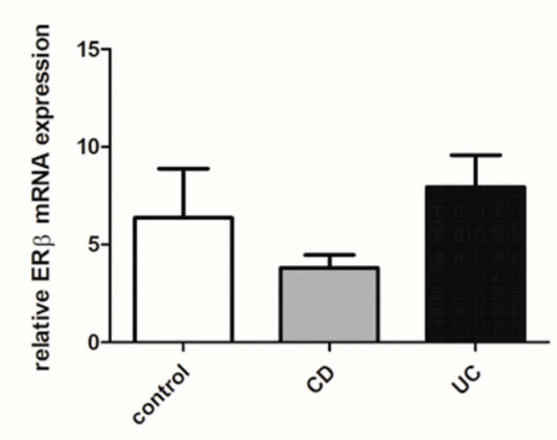

d

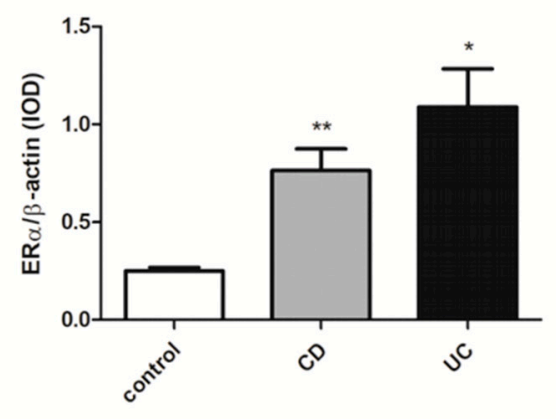

f

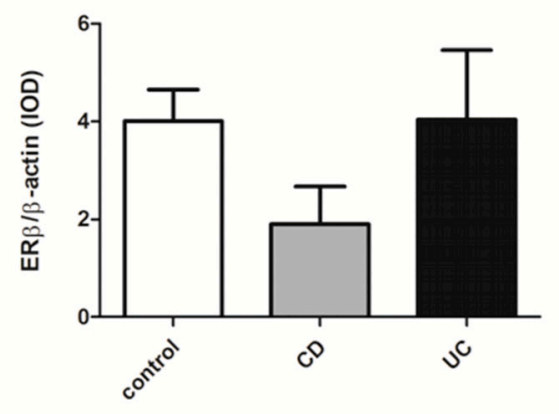

g

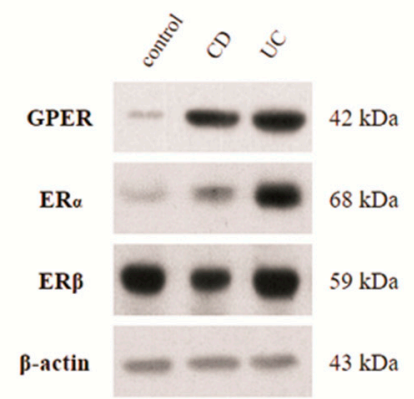

Figure 4. Expression of GPER $(\mathbf{a}, \mathbf{b}), \operatorname{ER} \alpha(\mathbf{c}, \mathbf{d})$ and $\operatorname{ER} \beta(\mathbf{e}, \mathbf{f})$ at the $\operatorname{mRNA}(\mathbf{a}, \mathbf{c}, \mathbf{e})$ and protein level $(\mathbf{b}, \mathbf{d}, \mathbf{f})$ in males with CD and UC and related controls (control, $n=12 ; \mathrm{CD}, n=19 ; \mathrm{UC}, n=24$ ). Representative immunoblots of GPER, ER $\alpha$ and ER $\beta(\mathrm{g})$. Values are means $\pm \mathrm{SEM} ;{ }^{*} P<0.05,{ }^{* *} P<0.01$ vs. control.

\subsection{Estrogen Receptors Expression in Women with IBD under the Age of 50}

Analysis of the expression of estrogen receptors in the material from women with IBD showed a decrease of GPER mRNA expression in CD $(P=0.047)$ and no changes in UC patients under the age of 50 compared to the control group (Figure 5a). However, women with IBD under the age of 50 were characterized by overexpression of GPER protein although a statistical significance was detected only for UC $(P=0.021)$ (Figure $5 b)$. No statistically significant differences were found in the expression of $\mathrm{ER} \alpha$ in women with IBD under the age of 50 (Figure 5c,d). Statistically significant down-regulation of ER $\beta$ transcript in both IBD subtypes ( $P=0.013$ for $C D$ and $P=0.035$ for UC) in women under the age of 50 compared to the control group was shown (Figure 5e). A lower, but not statistically significant, $\mathrm{ER} \beta$ protein level was also observed in colon samples collected from female patients under 50 years both with CD and UC (Figure 5f). 
a

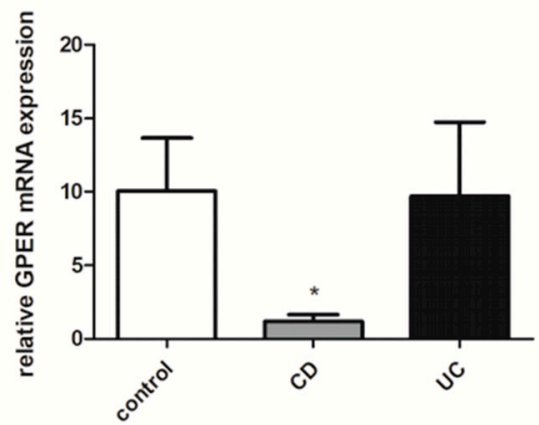

C

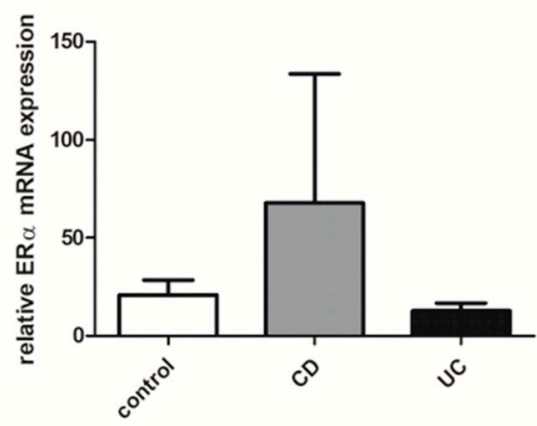

e

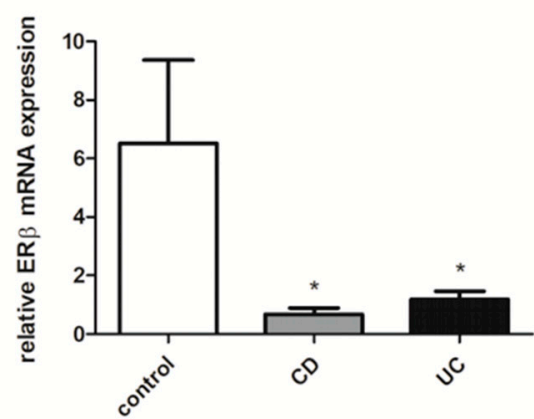

b

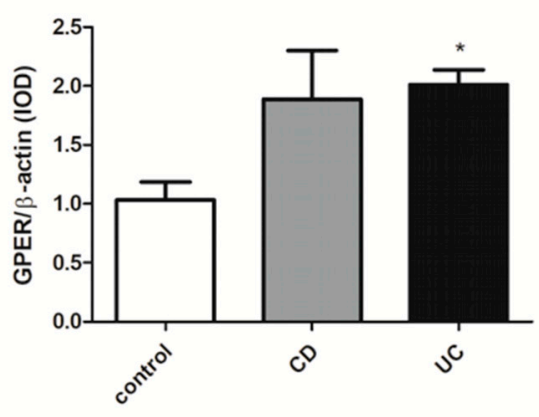

d

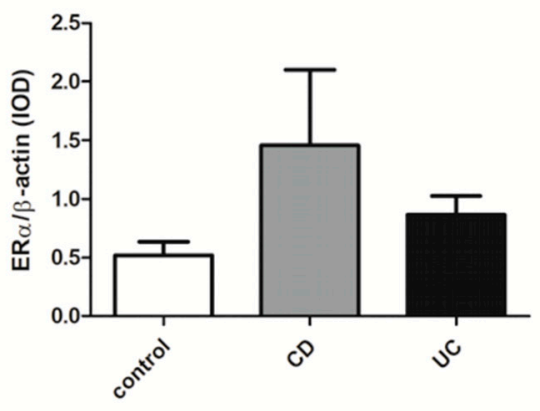

f

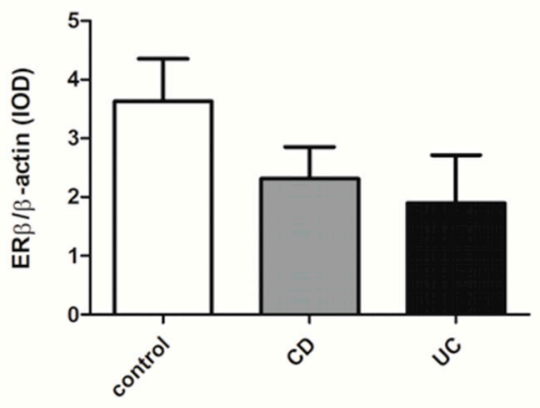

g

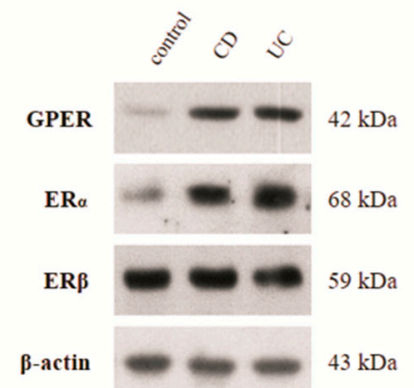

Figure 5. Expression of GPER $(\mathbf{a}, \mathbf{b}), \operatorname{ER} \alpha(\mathbf{c}, \mathbf{d})$ and $\operatorname{ER} \beta(\mathbf{e}, \mathbf{f})$ at the mRNA $(\mathbf{a}, \mathbf{c}, \mathbf{e})$ and protein level $(\mathbf{b}, \mathbf{d}, \mathbf{f})$ in females with CD and UC under the age of 50 years and related controls (control, $n=9 ; \mathrm{CD}$, $n=7$; UC, $n=12$ ). Representative immunoblots of GPER, ER $\alpha$ and ER $\beta(g)$. Values are means $\pm \mathrm{SEM}$; ${ }^{*} P<0.05$ vs. control. 


\subsection{Estrogen Receptors Expression in Women with IBD over the Age of 50}

In colon samples obtained from women with IBD over the age of 50 when compared to the control group, no statistically significant differences were found in GPER expression (Figure 6a,b). Statistically significant up-regulation of ER $\alpha$ mRNA expression was observed in women with CD over the age of $50(P=0.020)$ but not in women with UC in relation to the control group (Figure 6c). However, in the case of protein analysis, women with UC over the age of 50 were characterized by a statistically significant higher protein level of $\operatorname{ER} \alpha(P=0.003)$ (Figure $6 \mathrm{~d})$. No changes were observed in the ER $\alpha$ protein level in women with CD over the age of 50 compared to the control group. In the case of ER $\beta$ analysis, a statistically significant decrease of both mRNA and protein level was identified in samples taken from women with CD over the age of $50(P=0.027$ and $P=0.029$, respectively) (Figure 6e,f). The relative ER $\beta$ mRNA and protein level in UC was at a similar level to that in the control group.

a

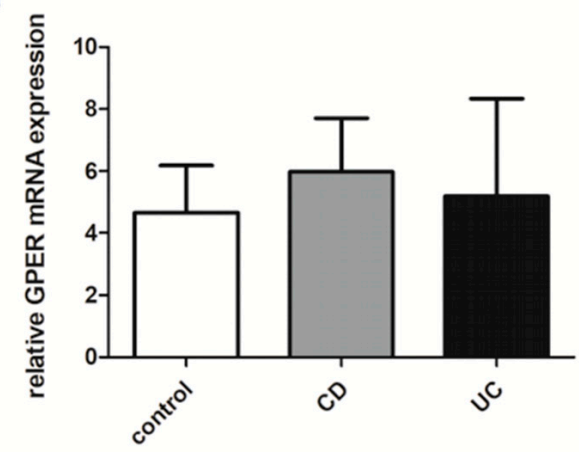

C

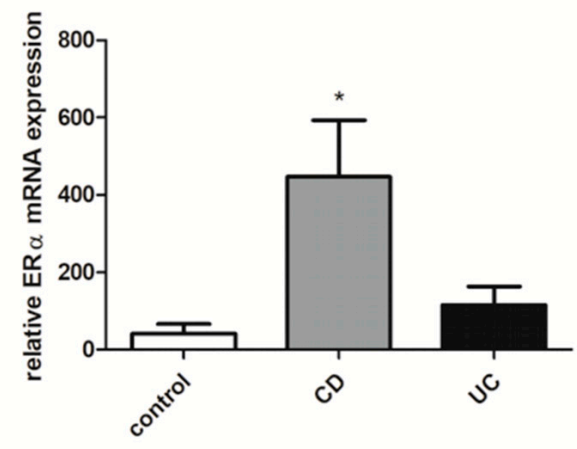

e

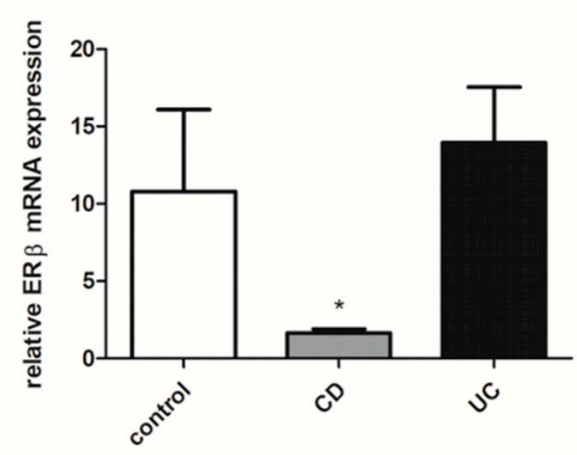

b

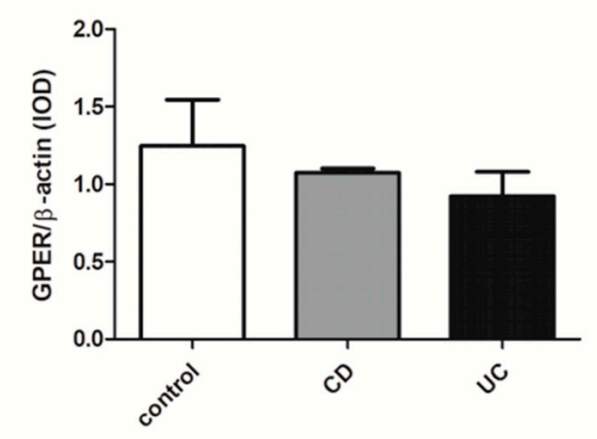

d

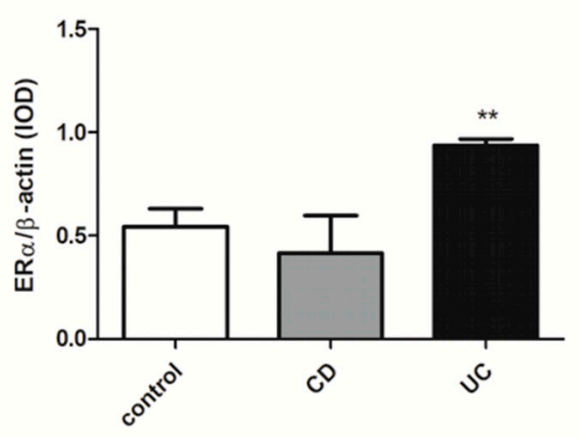

$\mathbf{f}$

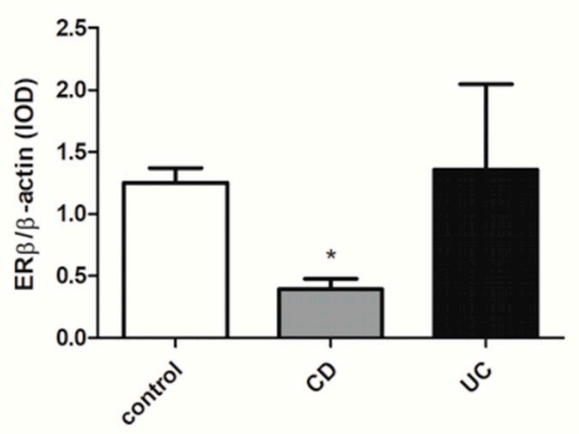

Figure 6. Cont. 


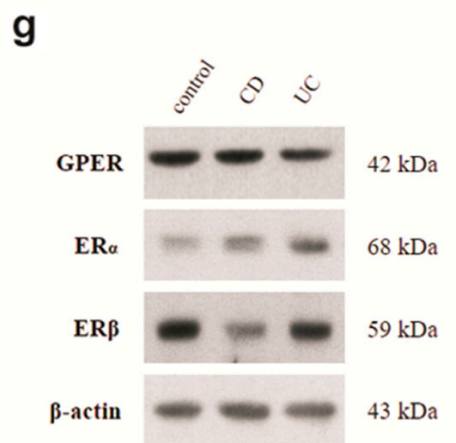

Figure 6. Expression of GPER $(\mathbf{a}, \mathbf{b}), \operatorname{ER} \alpha(\mathbf{c}, \mathbf{d})$ and $\operatorname{ER} \beta(\mathbf{e}, \mathbf{f})$ at the mRNA $(\mathbf{a}, \mathbf{c}, \mathbf{e})$ and protein level $(\mathbf{b}, \mathbf{d}, \mathbf{f})$ in females with CD and UC over the age of 50 years and related controls (control, $n=10 ; C D$, $n=5$; UC, $n=6$ ). Representative immunoblots of GPER, ER $\alpha$ and ER $\beta$ (g). Values are means \pm SEM;

${ }^{*} P<0.05,{ }^{* *} P<0.01$ vs. control.

\subsection{Estrogen Receptor ER $\alpha$ Spliced Variants Expression in IBD Patients}

Analysis of estrogen receptors in IBD patients also showed a disruption in the expression of ER $\alpha$ spliced variants, i.e., ER $\alpha 36$ and ER $\alpha 46$ in a sex- and age- dependent manner. There was a statistically significant reduction of ER $\alpha 36$ transcript in colon samples taken from men with CD $(P=0.029)$ in relation to the control group (Figure 7b). Similar to the men with IBD, the ER $\alpha 36$ mRNA expression pattern can be seen in women with IBD over the age of 50 (Figure 7d). In contrast, higher, but not statistically significant, expression of ER $\alpha 36$ mRNA was found in women with CD under the age of 50 compared to the control group (Figure 7c). In the case of ER $\alpha 46$, mRNA expression was shown to increase significantly in men with both types of IBD $(P=0.002$ and $P=0.001$ for CD and UC, respectively) compared to the control group (Figure $8 \mathrm{~b}$ ). A similar trend was observed in women with $\mathrm{CD}$ under and over the age of 50, but only in women with $\mathrm{CD}$ over the age of 50, the increase was statistically significant $(P=0.028)$ (Figure $8 c, d)$.

a

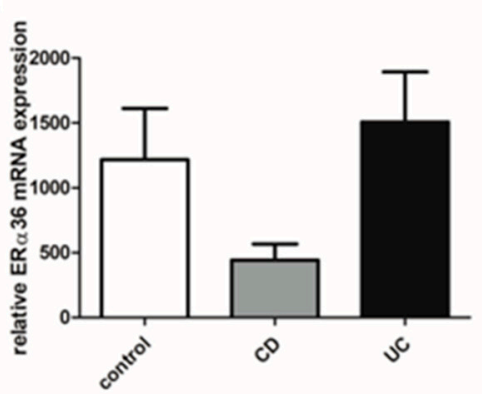

C

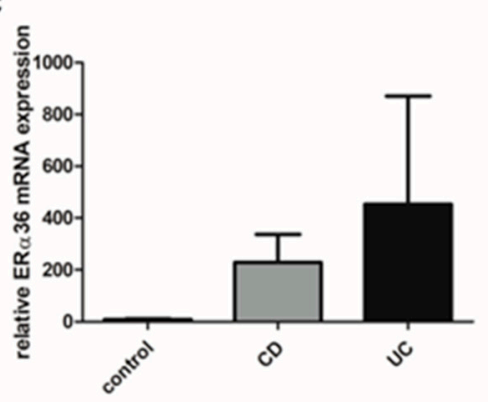

b

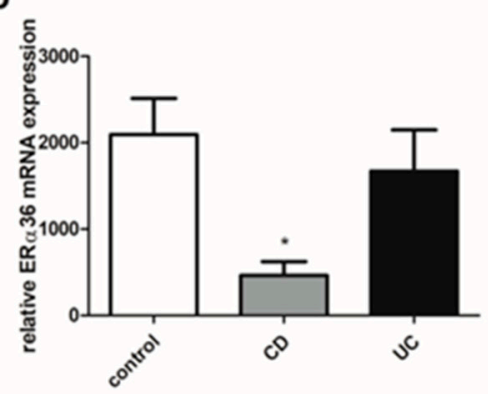

d

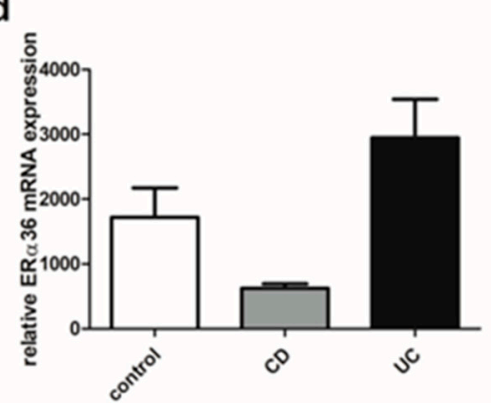

Figure 7. Cont. 
e

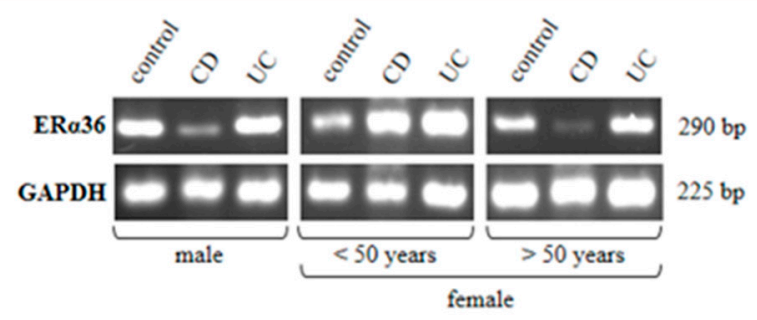

Figure 7. Expression of ER $\alpha 36$ at mRNA level in $\mathrm{CD}$ and $\mathrm{UC}$ patients and the control group regardless of sex and age (a; control, $n=31 ; \mathrm{CD}, n=31 ; \mathrm{UC}, n=42)$, males with CD and UC (b; control, $n=12 ; \mathrm{CD}$, $n=19$; UC, $n=24)$, females with CD an UC under the age of 50 years (c; control, $n=9 ; \mathrm{CD}, n=7$; UC, $n=12)$, females with CD and UC over the age of 50 years and related controls (d; control, $n=10 ; \mathrm{CD}$, $n=5$; UC, $n=6$ ). Representative agarose gel image of ER $\alpha 36$ expression $(\mathbf{e})$. Values are means \pm SEM; ${ }^{*} P<0.05$ vs. control.

a

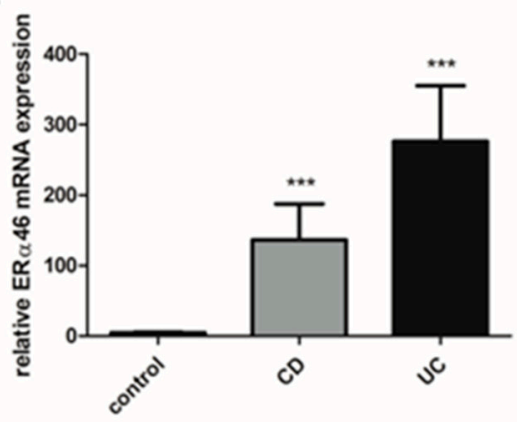

C

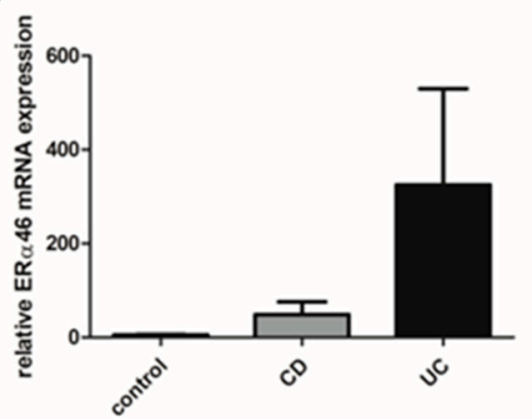

b

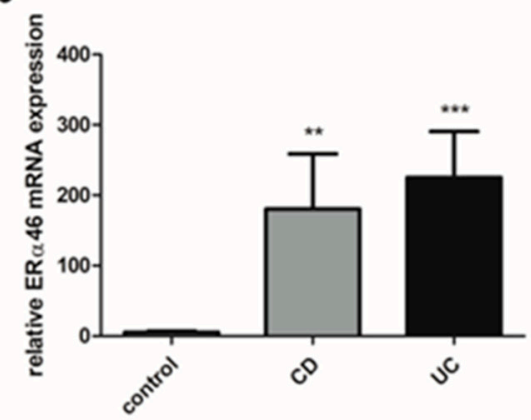

d

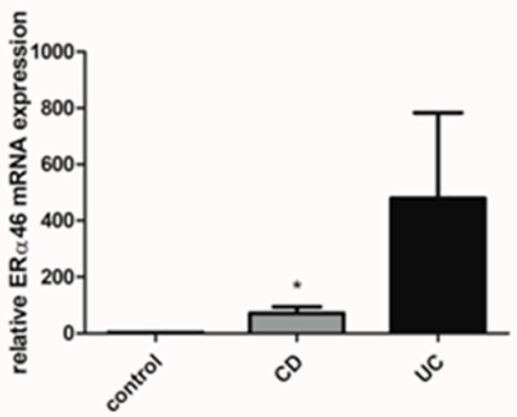

e

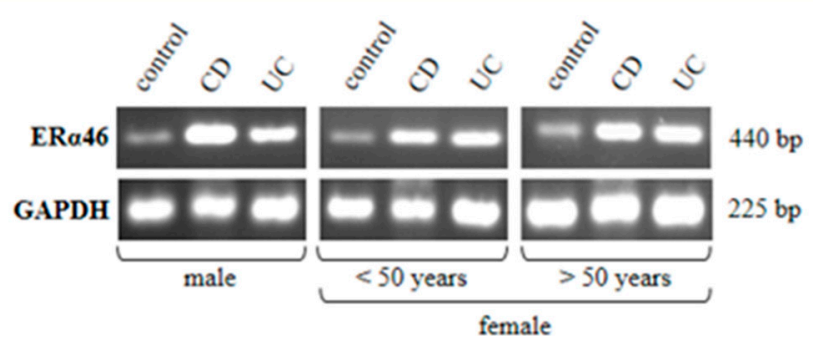

Figure 8. Expression of ER $\alpha 46$ at mRNA level in $\mathrm{CD}$ and UC patients and the control group regardless of sex and age (a; control, $n=31 ; \mathrm{CD}, n=31 ; \mathrm{UC}, n=42$ ), male with $\mathrm{CD}$ and $\mathrm{UC}$ ( $\mathbf{b}$; control, $n=12 ; \mathrm{CD}$, $n=19$; UC, $n=24)$, females with CD an UC under the age of 50 years (c; control, $n=9 ; \mathrm{CD}, n=7$; UC, $n=12$ ), females with CD and UC over the age of 50 years and related controls (d; control, $n=10 ; C D$, $n=5$; UC, $n=6$ ). Representative agarose gel image of ER $\alpha 46$ expression (e). Values are means \pm SEM; ${ }^{*} P<0.05,{ }^{* *} P<0.01$, ${ }^{* * *} P<0.001$ vs. control. 


\section{Discussion}

The pathogenesis of inflammatory bowel diseases remains elusive. There are a few main factors responsible for development of IBD, such as genetic and environmental factors which can lead to epithelial barrier dysfunction and dysregulation of immune response [23-25]. On the other hand, there is evidence of the anti-inflammatory effects of estrogens, especially the most active form, i.e., 17ß-estradiol [16]. Bábičková et al. [26] found differences related to sex in dextran sodium sulfate (DSS)-induced experimental colitis that suggest a protective role of $17 \beta$-estradiol in the development and severity of disease. Male mice were found to be more prone to colitis, which was manifested by worse microscopic and stool score, colon shortening and a higher level of TNF- $\alpha$ in relation to DSS-treated females. We identified that the serum level of $17 \beta$-estradiol in both male and female patients with IBD under and over the age of 50 remains within the normal range. Similarly, our analysis revealed no changes in CYP1A1 protein level in CD and UC regardless of the sex and age of the patients. Next, the same level of SULT1E1 in men and women with IBD irrespective of age was observed. CYP1A1 and SULT1E1 are enzymes involved in estrogen catabolism. CYP1A1 is responsible for the hydroxylation of estrogens to 2-hydroxyestrogens which bind to estrogen receptors with less affinity compared to $17 \beta$-estradiol. SULT1E1 takes part in the sulfation pathway where it is responsible for the conversion of estrogens to inactive metabolite by conjugation of a sulfo-group to estrone and 17ß-estradiol [27].

To elucidate the involvement of estrogen signaling mediated via estrogen receptors in IBD, we investigated the local intestine expression pattern of $G$ protein-coupled estrogen receptor (GPER), and nuclear estrogen receptors, $E R \alpha$ and $E R \beta$, as well as spliced variants of wild type ER $\alpha-E R \alpha 36$ and ER $\alpha 46$. Most of the research so far has focused on the role of ER $\beta$ in the gastrointestinal tract. It was estimated that ER $\beta$ plays an important role in the colon and appears to be responsible for several processes involved in the physiology and pathophysiology of the gastrointestinal tract. Based on immunohistochemical analysis reduced ER $\beta$ protein level in intestinal mucosa from patients with active CD and UC as compared to those in remission and healthy controls has been demonstrated [19]. Pierdominici et al. [19] also demonstrated lower ER $\beta$ expression in peripheral blood $\mathrm{T}$ cells in IBD patients with active disease and patients not responding to anti-TNF- $\alpha$ therapy. A higher pro-inflammatory level of cytokines in the plasma of these patients was observed, but only an inverse correlation of IL- 6 with ER $\beta$ expression was found. In Caco-2 cell-derived epithelium, ER $\beta$ down-regulation after IL-6 supplementation was confirmed. It has been shown that the immunomodulatory action of estrogens is partially related to ER $\beta$. However, Armstrong et al. [28] demonstrated inflammation score reduction in the middle and distal colon in 2, 4, 6-trinitrobenzensulfonic acid (TNBS)-induced murine model of acute colon inflammation not only after $17 \beta$-estradiol treatment, but also in TNBS-treated mice with the absence of ER $\beta$. Additionally, $17 \beta$-estradiol supplementation caused down-regulation of pro-inflammatory cytokines in both models, but in ER $\beta$ knock-out mice only a statistically significant reduction of IL-6 and INF- $\gamma$ was found. It has also been demonstrated that enriched nutritional formulation with ER $\beta$ agonist and anti-inflammatory properties may prevent inflammation-associated colorectal cancer in an animal model [29,30].

Although Pierdominici et al. [19] showed that in T cells from IBD patients, a reduction in ER $\beta$ expression was accompanied by a significant increase in ER $\alpha$ expression, no differences were observed in the ER $\alpha$ level between patients with CD an UC. Looijer-van Langen et al. [20] also observed no differences between males and females in the level of ER $\beta$ mRNA in the colonic biopsies from IBD patients. However, it has been suggested that the serum balance of nuclear estrogen receptors may be crucial for intestine homeostasis and a lower value of ER $\beta / E R \alpha$ ratio may be useful for the monitoring of CD but not UC activity. Down-regulation of the ER $\beta / E R \alpha$ ratio in serum was demonstrated in $C D$ patients with active disease in relation to $C D$ patients in remission [31]. The reduction of ER $\beta$ expression and the concomitant increase of ER $\alpha$ in peripheral blood T cells in patients with IBD, as well as the ER $\beta / E R \alpha$ ratio in the serum of IBD patients, have been shown to be not related to the gender and age of the patients $[19,31]$. However, in our investigations involving more than twice as many patients 
as in the mentioned studies, we observed a deregulation of the expression of all studied estrogen receptors in the colonic mucosa of both $\mathrm{CD}$ and UC patients in a gender and age-dependent manner. Up-regulation of GPER and ER $\alpha$ has been documented in intestinal samples obtained from men with $\mathrm{CD}$ and UC. In the case of women, the dysregulation of estrogen receptor expression appears to depend not only on the gender but also on the age of patients. Women under the age of 50 were characterized by lower mRNA expression of GPER in CD. However, at the protein level, GPER up-regulation was observed in UC. There is well-known discrepancy between the level of mRNA and the predicted level of the encoded protein in a particular cell. This was confirmed by a study of global transcriptomics and proteomic analysis, which showed that only approximately $30 \%$ of the changes in mRNA levels could be correlated with protein levels [32]. Undoubtedly, post-transcriptional modifications have an impact on the activity and stability of the proteins and adds more complexity to the protein. There were no significant differences in the ER $\beta$ protein level between women with CD or UC under the age of 50 and the control group, although a statistically significant reduction in the expression of this receptor at the transcript level was found. However, in women with CD over 50 years of age, a statistically significant decrease of ER $\beta$ was stated at both the mRNA and protein levels. A higher statistically significant ER $\alpha$ protein level has been documented in women with UC over the age of 50, while no alteration in GPER expression was observed in women with IBD over the age of 50 years.

There is no doubt that not only ER $\beta$ but also ER $\alpha$ and GPER are important for the proper architecture and functioning of colon crypts [33]. ER $\beta$ is thought to negatively regulate the activity of ER $\alpha$ [34-36]. Kang et al. [37] indicated that down-regulation of ER $\alpha 36$ at the transcription level is mediated via GPER. In our previous study we showed that GPER is overexpressed in colon samples obtained from male mice treated with TNBS. However, administration of $17 \beta$-estradiol or G-1, a selective GPER agonist, reduced GPER expression at the mRNA and protein level and was associated with improved colitis scores as well as CRP protein level. In addition, the treatment of CD mice with GPER agonists or antagonists was associated with changes in the level of expression in the colon of nuclear estrogen receptors, i.e., ER $\alpha$ and ER $\beta$ [22]. Several reports indicate that GPER may play a significant role in immune response [38,39]. Differences in GPER protein levels between non-inflamed and inflamed area in mucosa samples of CD were demonstrated [40]. Additionally, GPER was found to be well distributed in immune cells such as macrophages, neutrophils, B and T cells [41]. Interestingly, a GPER-mediated decrease of phagocytic activity and nitric oxide production during LPS-induced microglial activation in N9 cells was observed [42]. Next, Zhao et al. [43] have shown that G-1, a selective agonist of GPER is able to reduce pro-inflammatory cytokines such as interleukin-1 $\beta$ (IL-1 $\beta$ ) and TNF- $\alpha$ in the primary microglia culture.

The results collectively indicate that in $\mathrm{CD}$ and $\mathrm{UC}$, alterations of estrogen receptor expression may be associated with the sex and age of patients. Our study shows the complexity of estrogen signaling in the pathophysiology of IBD and gives an insight into the potential mechanisms by which gender and age-related differences in intestinal inflammation can arise. Understanding the mechanisms related to the participation of estrogen receptors in inflammatory bowel diseases depending on the gender and age of the patient may be important for improving the treatment of CD and UC. Furthermore, IBD represents a risk factor for the development of colorectal cancer, and inflammation-associated estrogen receptor dysregulation might be one of the factors linking chronic intestinal diseases to neoplastic transformation.

\section{Materials and Methods}

\subsection{Study Group and Colon Mucosa Sample Collection}

In total, 73 patients with IBD (CD, $n=31$; UC $n=42)$ and 31 sex and age-related controls were enrolled in the study. The demographic characteristics of patients are shown in Table 3. IBD was evaluated based on clinical, radiological, endoscopical and histological criteria recommended by the European Crohn's and Colitis Organization. IBD samples were obtained from non-inflamed 
regions of the colon from patients before the initiation of therapy. Control biopsy specimens were obtained from routine colonoscopy screenings of IBD-free patients. Women were not OC or HRT users. Material was collected by gastroenterologists from the Department of Digestive Tract Disease, Faculty of Medicine at the Medical University of Lodz, Poland. Serum and forceps endoscopic biopsies of colon were taken during hospitalization. The material was frozen and kept at $-80^{\circ} \mathrm{C}$ for further analysis. The study was conducted in accordance with the ethical principles of the 1975 Declaration of Helsinki and the independent Bioethics Committees of the Medical University of Lodz and the University of Lodz approved the study protocols. All participating subjects gave written, informed consent prior to enrollment.

Table 3. Demographic profiles of control subjects and IBD patients enrolled in the study.

\begin{tabular}{|c|c|c|c|c|}
\hline & $\begin{array}{l}\text { Subjects and Age } \\
\text { of Subjects }\end{array}$ & Control & CD & UC \\
\hline \multirow{3}{*}{ Total } & $n$ & 31 & 31 & 42 \\
\hline & mean \pm SD & $63.08 \pm 15.79$ & $48.40 \pm 17.55$ & $45.22 \pm 12.63$ \\
\hline & range & $22-86$ & $29-86$ & $22-81$ \\
\hline \multirow{3}{*}{ Male } & $n$ & 12 & 19 & 24 \\
\hline & mean $\pm \mathrm{SD}$ & $63.27 \pm 12.67$ & $49.43 \pm 48.90$ & $43.24 \pm 11.07$ \\
\hline & range & $32-83$ & $29-86$ & $29-65$ \\
\hline \multirow{3}{*}{$\begin{array}{l}\text { Female under the } \\
\text { age of } 50 \text { years }\end{array}$} & $n$ & 9 & 7 & 12 \\
\hline & mean $\pm \mathrm{SD}$ & $41.60 \pm 9.52$ & $36.14 \pm 7.92$ & $39.43 \pm 6.26$ \\
\hline & range & $22-49$ & $29-48$ & $22-47$ \\
\hline \multirow{3}{*}{$\begin{array}{l}\text { Female over the } \\
\text { age of } 50 \text { years }\end{array}$} & $n$ & 10 & 5 & 6 \\
\hline & mean $\pm \mathrm{SD}$ & $73.60 \pm 9.69$ & $66.25 \pm 3.30$ & $65.00 \pm 9.59$ \\
\hline & range & $57-86$ & $64-71$ & $52-81$ \\
\hline
\end{tabular}

\subsection{Enzyme-Linked Immunosorbent Assay}

For determination of $17 \beta$-estradiol levels in human serum, a dedicated commercially available kit (Demeditec Diagnostics, Kiel, Germany) was used. Ninety-six-well plates were coated with $25 \mu \mathrm{L}$ of calibrators $(0,25,75,225,675,2000 \mathrm{pg} / \mathrm{mL})$, low positive control $(95 \mathrm{pg} / \mathrm{mL})$, high positive control $(252 \mathrm{pg} / \mathrm{mL})$ and samples and incubated over $60 \mathrm{~min}$ at room temperature on a plate shaker $(>600 \mathrm{rpm})$. $100 \mu \mathrm{L}$ of enzyme conjugate was added and the plates were incubated as above. Thereafter, the plates were washed four times with wash solution and $200 \mu \mathrm{L}$ of substrate solution was added to each well. After $30 \mathrm{~min}$, the reaction was stopped by adding $50 \mu \mathrm{L}$ of stop solution.

For determination of CYP1A1and SULT1E1 level in human serum ninety-six-well plates were coated overnight at $4{ }^{\circ} \mathrm{C}$ with $100 \mu \mathrm{L}$ of antigen in $50 \mathrm{mM}$ carbonate buffer, $\mathrm{pH}$ 9.6. Subsequently, the plates were incubated with commercially available primary antibodies (dilution 1:100, Santa Cruz Biotechnology, Dallas, TX, USA) against CYP1A1 (sc-393979) and SULT1E1 (sc-376009) for three hours at room temperature. Next, the plates were incubated for one hour at room temperature with secondary antibodies (dilution 1:1000) coupled with horseradish peroxidase (HRP; Thermo Scientific, Waltham, MA, USA). O-phenylenediamine dihydrochloride (OPD; Sigma Aldrich, Munich, Germany) was used as a substrate for HRP. The reaction with OPD was stopped with $40 \% \mathrm{H}_{2} \mathrm{SO}_{4}$. The optimal concentration for each examined protein and antibody was evaluated by titration. The same protocol was used for negative controls (without antigen, primary or secondary antibody). Absorbance was read at $450 \mathrm{~nm}$ in a Micro Plate Reader (Bio-Rad, Hercules, CA, USA). All experiments were performed in triplicate. 


\subsection{RNA Isolation}

RNA extraction was performed using commercially available TRIsure ${ }^{\mathrm{TM}}$ reagent (Bioline, London, UK). Tissue samples were minced and homogenized in TRIsure ${ }^{\mathrm{TM}}$. After centrifugation and phase separation, aqueous phase was mixed 3:1 (v/v) with isopropanol and loaded into the column. Subsequent steps were conducted according to manufacturer's protocol (microRNA Concentrator; A\&A Biotechnology, Gdynia, Poland). The purity and quantity of RNA was estimated spectrophotometrically with BioPhotometer Plus (Eppendorf, Hamburg, Germany). The RNA was characterized with $A_{260}$ $\mathrm{nm} / \mathrm{A}_{280} \mathrm{~nm}$ ratio, which was in the range of $1.70-2.00$.

\subsection{Real-Time PCR}

cDNA synthesis was performed with a High-Capacity cDNA Reverse Transcription Kit (Applied Biosystems, Waltham, MA, USA) in accordance with the manufacturer's protocol. $1 \mu \mathrm{g}$ of RNA was used in a reverse transcription reaction with the following incubation steps: $25^{\circ} \mathrm{C}$ for ten minutes, $37^{\circ} \mathrm{C}$ for $120 \mathrm{~min}$ and $85^{\circ} \mathrm{C}$ for five minutes. Quantification of mRNA expression was performed using the real-time PCR method with FAM dye-labeled TaqMan ${ }^{\circledR}$ probes (Applied Biosystems, Waltham, MA, USA) and specific primers (Sigma Aldrich, Munich, Germany). The reaction mixture consisted of cDNA, TaqMan ${ }^{\circledR}$ Master Mix II, no UNG, TaqMan ${ }^{\circledR}$ Assays (GPER: Hs00173506_m1, ER $\alpha$ : Hs00174860_m1, ERß: Hs01100358_m1, IL-6: Hs00985639_m1, IL-10: Hs00961622_m1, CCL18: Hs00268113_m1, TNF- $\alpha$ : Hs01113624_g1, NFkB (RELA): Hs00153294_m1, GAPDH: Hs99999905_m1), and RNase-free water in total volume of $10 \mu \mathrm{L}$. For ER $\alpha 36, \mathrm{ER} \alpha 46$ and GAPDH, the mixture consisted of cDNA, PowerUp ${ }^{\mathrm{TM}}$ SYBR $^{\mathrm{TM}}$ Green Master Mix (Applied Biosystems, Waltham, MA, USA), forward primer, reverse primer and RNase-free water in total volume of $10 \mu \mathrm{L}$. Sequences of primer sets were designed using bioinformatic databases such as NCBI gene, ENSEMBL, MUSCLE and Primer-BLAST and are shown in Table 4. Cycle parameters for TaqMan ${ }^{\circledR}$ Assays were as follows: initial denaturation at $95^{\circ} \mathrm{C}$ for ten minutes, followed by 40 cycles of sequential incubations at $95^{\circ} \mathrm{C}$ for $15 \mathrm{~s}$ and at $60^{\circ} \mathrm{C}$ for one minute. Cycle parameters for the reaction with the PowerUp ${ }^{\mathrm{TM}} \mathrm{SYBR}^{\mathrm{TM}}$ Green Master Mix were as follows: UDG activation at $50^{\circ} \mathrm{C}$ for two minutes and Dual-Lock ${ }^{\mathrm{TM}}$ DNA polymerase at $95^{\circ} \mathrm{C}$ for two minutes, followed by 40 cycles of sequential incubations at $95^{\circ} \mathrm{C}$ for $15 \mathrm{~s}$ and at $60^{\circ} \mathrm{C}$ for one minute and the obtained results were normalized to the expression of GAPDH. Real-time PCR products were verified during agarose gel electrophoresis. All experiments were performed in triplicate. The reaction was performed using a Mastercycler ${ }^{\circledR}$ ep Realplex4s (Eppendorf, Hamburg, Germany). The fluorescent dye emission was a function of the cycle number. The initial amount of the template was evaluated as a $\mathrm{Ct}$ parameter. $\mathrm{Ct}$ value corresponded to the threshold cycle number at which PCR amplification reached a significant threshold. The relative expression level was calculated as $2^{-\Delta \mathrm{Ct}} \times 1000$.

Table 4. Primer sequences and the length of the amplicons of ER $\alpha$ splice variants and the housekeeping gene.

\begin{tabular}{cccc}
\hline Gene & Primer & Sequence & Amplicon Length (bp) \\
\hline \multirow{2}{*}{ ER $\alpha 36$} & $\begin{array}{c}\text { Forward } \\
\text { Reverse }\end{array}$ & $\begin{array}{c}\text { CAAGTGGTTTCCTCGTGTCTAAAG } \\
\text { TGTTGAGTGTTGGTTGCCAGG }\end{array}$ & 290 \\
\hline \multirow{2}{*}{ ER $\alpha 46$} & $\begin{array}{c}\text { Forward } \\
\text { Reverse }\end{array}$ & $\begin{array}{c}\text { GTGCTCCCCAAATTTCCTTTCA } \\
\text { GCCTTCGCCATTGAAGTCAC }\end{array}$ & 440 \\
\hline \multirow{2}{*}{ GAPDH } & $\begin{array}{c}\text { Forward } \\
\text { Reverse }\end{array}$ & $\begin{array}{c}\text { CTTCGCTCTCTGCTCCTCCTGTTCG } \\
\text { ACCAGGCGCCCAATACGACCAAAT }\end{array}$ & 225 \\
\hline
\end{tabular}

\subsection{Western Blot Analysis}

Proteins were isolated in $100 \mu \mathrm{L}$ of the radioimmunoprecipitation assay buffer (RIPA; $50 \mathrm{mM}$ Tris/HCl, pH 7.6; $150 \mathrm{mM} \mathrm{NaCl}$; $1 \%$ Triton X-100; 0.1\% SDS; 1\% sodium deoxycholate; 2 mM EDTA) supplemented with $1 \mathrm{mM}$ phenylmethanesulfonyl fluoride (PMSF) using an ultrasonic homogenizer (Sonic\&Meterials, Newtown, CT, USA). The homogenates were cleared by centrifugation at $5000 \mathrm{rpm}$ 
for ten minutes. Total protein concentration was evaluated in each sample in triplicate using the Lowry protocol. $10 \mu \mathrm{g}$ of protein samples were separated on $8 \%$ polyacrylamide gels in electrophoresis buffer (25 mM Tris; $192 \mathrm{mM}$ glycine; 0.1\% SDS) and electrotransferred onto polyvinyl difluoride (PVDF) membranes (pore size $0.45 \mu \mathrm{m}$, Thermo Scientific, Waltham, MA, USA) in transfer buffer $(25 \mathrm{mM}$ Tris; $192 \mathrm{mM}$ glycine; 20\% methanol) using the wet system. Membranes were blocked $60 \mathrm{~min}$ in 5\% casein and incubated overnight at $4{ }^{\circ} \mathrm{C}$ with commercially available (Abcam, Cambridge, UK) primary antibodies (dilution 1:1000) against GPER (ab39742), ER $\alpha$ (ab75635) or ER $\beta$ (ab3576). Subsequently, the membranes were incubated with secondary antibodies (dilution 1:5000) coupled with HRP (31460, Thermo Scientific, Waltham, MA, USA). The optimal concentration of antibodies was selected before the final experiment. After stripping with a buffer containing $10 \%$ SDS; $0.5 \mathrm{M}$ Tris/ $\mathrm{HCl}, \mathrm{pH} 6.8 ; 0.8 \%$ $\beta$-mercaptoethanol, a separate analysis for each sample was performed using $\beta$-actin antibodies conjugated with horseradish peroxidase (HRP) (dilution 1:1000, sc-47778, Santa Cruz Biotechnology, Dallas, TX, USA). Immunereaction was visualized using Clarity ${ }^{\mathrm{TM}}$ Western ELC Substrate (Bio-Rad, Hercules, CA, USA) and X-ray films (Fujifilm, Tokyo, Japan). The intensities of the visualized signals were analyzed densitometrcially by using Gel Pro Analyzer v3.0 for Windows (Media Cybernetics, Rockville, MD, USA).

\subsection{Statistical Analysis}

Statistical analysis was performed using GraphPad Prism 5.0 (GraphPad Software Inc., San Diego, CA, USA). All data are presented as means \pm standard error of mean (SEM). The non-parametric Mann-Whitney $\mathrm{U}$ test was used for comparison of the studied groups. $P$-values $<0.05$ were considered statistically significant.

Author Contributions: Conceptualization, D.J. and W.M.K.; Methodology, D.J. and A.I.C.; Formal Analysis, D.J.; Investigation, D.J. and W.M.K.; Resources, A.M., E.M.-P. and J.F.; Data Curation, D.J.; Writing, Original Draft Preparation, D.J.; Writing, Review \& Editing, D.J., J.F. and W.M.K.; Supervision, W.M.K.

Funding: This work was supported by grants (2017/24/T/NZ5/00045 and 2015/17/N/NZ5/00336 to D.J.) from the National Science Centre, Poland.

Conflicts of Interest: The authors declare no conflict of interest.

\section{References}

1. Ananthakrishnan, A.N. Epidemiology and risk factors for IBD. Nat. Rev. Gastroenterol. Hepatol. 2015, 12, 205-217. [CrossRef] [PubMed]

2. Nanini, H.F.; Bernardazzi, C.; Castro, F.; de Souza, H.S.P. Damage-associated molecular patterns in inflammatory bowel disease: From biomarkers to therapeutic targets. World J. Gastroenterol. 2018, 24, 4622-4634. [CrossRef] [PubMed]

3. Wittkopf, N.; Neurath, M.F.; Becker, C. Immune-epithelial crosstalk at the intestinal surface. J. Gastroenterol. 2014, 49, 375-387. [CrossRef] [PubMed]

4. Bernstein, C.N.; Wajda, A.; Svenson, L.W.; MacKenzie, A.; Koehoorn, M.; Jackson, M.; Fedorak, R.; Israel, D.; Blanchard, J.F. The epidemiology of inflammatory bowel disease in Canada: A population-based study. Am. J. Gastroenterol. 2006, 101, 1559-1568. [CrossRef] [PubMed]

5. Molinié, F.; Gower-Rousseau, C.; Yzet, T.; Merle, V.; Grandbastien, B.; Marti, R.; Lerebours, E.; Dupas, J.L.; Colombel, J.F.; Salomez, J.L.; et al. Opposite evolution in incidence of Crohn's disease and ulcerative colitis in Northern France (1988-1999). Gut 2004, 53, 843-848. [CrossRef] [PubMed]

6. Khalili, H.; Higuchi, L.M.; Ananthakrishnan, A.N.; Richter, J.M.; Feskanich, D.; Fuchs, C.S.; Chan, A.T. Oral contraceptives, reproductive factors and risk of inflammatory bowel disease. Gut 2013, 62, 1153-1159. [CrossRef]

7. Khalili, H.; Granath, F.; Smedby, K.E.; Ekbom, A.; Neovius, M.; Chan, A.T.; Olen, O. Association between long-term oral contraceptive use and risk of Crohn's disease complications in a nationwide study. Gastroenterology 2016, 150, 1561-1567. [CrossRef] 
8. Khalili, H.; Higuchi, L.M.; Ananthakrishnan, A.N.; Manson, J.E.; Feskanich, D.; Richter, J.M.; Fuchs, C.S.; Chan, A.T. Hormone therapy increases risk of ulcerative colitis but not Crohn's disease. Gastroenterology 2012, 143, 1199-1206. [CrossRef]

9. García Rodríguez, L.A.; González-Pérez, A.; Johansson, S.; Wallander, M.A. Risk factors for inflammatory bowel disease in the general population. Aliment. Pharm. 2005, 22, 309-315. [CrossRef]

10. Kane, S.V.; Reddy, D. Hormonal replacement therapy after menopause is protective of disease activity in women with inflammatory bowel disease. Am. J. Gastroenterol. 2008, 103, 1193-1196. [CrossRef]

11. Betteridge, J.D.; Armbruster, S.P.; Maydonovitch, C.; Veerappan, G.R. Inflammatory bowel disease prevalence by age, gender, race, and geographic location in the U.S. military health care population. Inflamm. Bowel. Dis. 2013, 19, 1421-1427. [CrossRef] [PubMed]

12. Ortizo, R.; Lee, S.Y.; Nguyen, E.T.; Jamal, M.M.; Bechtold, M.M.; Nguyen, D.L. Exposure to oral contraceptives increases the risk for development of inflammatory bowel disease: A meta-analysis of case-controlled and cohort studies. Eur. J. Gastroenterol. Hepatol. 2017, 29, 1064-1070. [CrossRef] [PubMed]

13. Jacenik, D.; Cygankiewicz, A.I.; Krajewska, W.M. The G-protein-coupled estrogen receptor as a modulator of neoplastic transformation. Mol. Cell Endocrinol. 2016, 429, 10-18. [CrossRef] [PubMed]

14. Wang, Z.Y.; Yin, L. Estrogen receptor alpha-36 (ER- $\alpha 36)$ : A new player in human breast cancer. Mol. Cell Endocrinol. 2015, 3, 193-206. [CrossRef] [PubMed]

15. Romano, S.N.; Gorelick, D.A. Crosstalk between nuclear and G-protein-coupled estrogen receptors. Gen. Comp. Endocrinol. 2018, 261, 190-197. [CrossRef]

16. Straub, R.H. The complex role of estrogens in inflammation. Endocr. Rev. 2007, 28, 521-574. [CrossRef] [PubMed]

17. Clegg, D.J. Minireview: The year in review of estrogen regulation of metabolism. Mol. Endocrinol. 2012, 26, 1957-1960. [CrossRef] [PubMed]

18. Kovats, S. Estrogen receptors regulate innate immune cells and signaling pathways. Cell Immunol. 2015, 294, 63-69. [CrossRef] [PubMed]

19. Pierdominici, M.; Maselli, A.; Varano, B.; Barbati, C.; Cesaro, P.; Spada, C.; Zullo, A.; Lorenzetti, R.; Rosati, M.; Rainaldi, G.; et al. Linking estrogen receptor $\beta$ expression with inflammatory bowel disease activity. Oncotarget. 2015, 6, 40443-40451. [CrossRef] [PubMed]

20. Looijer-van Langen, M.; Hotte, N.; Dieleman, L.A.; Albert, E.; Mulder, C.; Madsen, K.L. Estrogen receptor- $\beta$ signaling modulates epithelial barrier function. Am. J. Physiol. Gastrointest. Liver. Physiol. 2011, 300, G621-G626. [CrossRef]

21. Goodman, W.A.; Havran, H.L.; Quereshy, H.A.; Kuang, S.; De Salvo, C.; Pizarro, T.T. Estrogen receptor $\alpha$ loss-of-function protects female mice from DSS-induced experimental colitis. Cell Mol. Gastroenterol. Hepatol. 2017, 5, 630.e1-633.e1. [CrossRef] [PubMed]

22. Jacenik, D.; Zielińska, M.; Mokrowiecka, A.; Michlewska, S.; Małecka-Panas, E.; Kordek, R.; Fichna, J.; Krajewska, W.M. G-protein-coupled estrogen receptor mediates anti-inflammatory action in Crohn's disease. Sci. Rep. 2019, 9, 6749. [CrossRef] [PubMed]

23. Loddo, I.; Romano, C. Inflammatory bowel disease: Genetics, epigenetics, and pathogenesis. Front. Immunol. 2015, 6, 551. [CrossRef] [PubMed]

24. Khor, B.; Gardet, A.; Xavier, R.J. Genetics and pathogenesis of inflammatory bowel disease. Nature 2011, 474, 307-317. [CrossRef] [PubMed]

25. Ananthakrishnan, A.N. Environmental risk factors for inflammatory bowel disease. Gastroenterol. Hepatol. 2013, 9, 367-374. [CrossRef] [PubMed]

26. Bábíčková, J.; Tóthová, L'.; Lengyelová, E.; Bartoňová, A.; Hodosy, J.; Gardlík, R.; Celec, P. Sex differences in experimentally induced colitis in mice: A role for estrogens. Inflammation 2015, 38, 1996-2006. [CrossRef] [PubMed]

27. Dumas, I.; Diorio, C. Estrogen pathway polymorphisms and mammographic density. Anticancer Res. 2011, $31,4369-4386$.

28. Armstrong, C.M.; Allred, K.F.; Weeks, B.R.; Chapkin, R.S.; Allred, C.D. Estradiol has differential effects on acute colonic inflammation in the presence and absence of estrogen receptor $\beta$ expression. Dig. Dis. Sci. 2017, 62, 1977-1984. [CrossRef] 
29. Principi, M.; Barone, M.; Pricci, M.; De Tullio, N.; Losurdo, G.; Ierardi, E.; Di Leo, A. Ulcerative colitis: From inflammation to cancer. Do estrogen receptors have a role? World J. Gastroenterol. 2014, 20, 11496-11504. [CrossRef]

30. Girardi, B.; Principi, M.; Pricci, M.; Giorgio, F.; Iannone, A.; Losurdo, G.; Ierardi, E.; Di Leo, A.; Barone, M. Chemoprevention of inflammation-related colorectal cancer by silymarin-, acetyl-11-keto-beta-boswellic acid-, curcumin- and maltodextrin-enriched dietetic formulation in animal model. Carcinogenesis 2018, 39, 1274-1282. [CrossRef]

31. Linares, P.M.; Algaba, A.; Urzainqui, A.; Guijarro-Rojas, M.; González-Tajuelo, R.; Garrido, J.; Chaparro, M.; Gisbert, J.P.; Bermejo, F.; Guerra, I.; et al. Ratio of circulating estrogen receptors beta and alpha (ER $\beta / E R \alpha)$ indicates endoscopic activity in patients with Crohn's Disease. Dig. Dis. Sci. 2017, 62, 2744-2754. [CrossRef] [PubMed]

32. Vogel, C.; Marcotte, E.M. Insights into the regulation of protein abundance from proteomic and transcriptomic analyses. Nat. Rev. Genet. 2012, 13, 227-232. [CrossRef] [PubMed]

33. Cho, N.L.; Javid, S.H.; Carothers, A.M.; Redston, M.; Bertagnolli, M.M. Estrogen receptor $\alpha$ and $\beta$ are inhibitory of Apc-dependent tumorigenesis in the proximal colon of Min/+ mice. Cancer Res. 2007, 67, 2366-2372. [CrossRef] [PubMed]

34. Liu, M.M.; Albanese, C.; Anderson, C.M.; Hilty, K.; Webb, P.; Uht, R.M.; Price, R.H., Jr.; Pestell, R.G.; Kushner, P.J. Opposing action of estrogen receptors $\alpha$ and $\beta$ on cyclin D1 gene expression. J. Biol. Chem. 2002, 277, 24353-24360. [CrossRef] [PubMed]

35. Matthews, J.; Wihlén, B.; Tujague, M.; Wan, J.; Ström, A.; Gustafsson, J.A. Estrogen receptor (ER) beta modulates ERalpha-mediated transcriptional activation by altering the recruitment of c-Fos and c-Jun to estrogen-responsive promoters. Mol. Endocrinol. 2006, 20, 534-543. [CrossRef] [PubMed]

36. Maruyama, K.; Endoh, H.; Sasaki-Iwaoka, H.; Kanou, H.; Shimaya, E.; Hashimoto, S.; Kato, S.; Kawashima, H. A novel isoform of rat estrogen receptor beta with 18 amino acid insertion in the ligand binding domain as a putative dominant negative regular of estrogen action. Biochem. Biophys. Res. Commun. 1998, 246, 142-147. [CrossRef] [PubMed]

37. Kang, L.; Zhang, X.; Xie, Y.; Tu, Y.; Wang, D.; Liu, Z.; Wang, Z.Y. Involvement of estrogen receptor variant ER- $\alpha 36$, not GPR30, in nongenomic estrogen signaling. Mol. Endocrinol. 2010, 24, 709-721. [CrossRef]

38. Prossnitz, E.R.; Hathaway, H.J. What have we learned about GPER function in physiology and disease from knockout mice? J. Steroid. Biochem. Mol. Biol. 2015, 153, 114-126. [CrossRef]

39. Prossnitz, E.R.; Arterburn, J.B. International Union of Basic and Clinical Pharmacology. XCVII. G-protein-Coupled Estrogen Receptor and its pharmacologic modulators. Pharm. Rev. 2015, 67, 505-540. [CrossRef]

40. Włodarczyk, M.; Sobolewska-Włodarczyk, A.; Cygankiewicz, A.I.; Jacenik, D.; Piechota-Polańczyk, A.; Stec-Michalska, K.; Krajewska, W.M.; Fichna, J.; Wiśniewska-Jarosińska, M. G-protein-Coupled Receptor 30 (GPR30) expression pattern in inflammatory bowel disease patients suggests its key role in the inflammatory process. A preliminary study. J. Gastrointestin. Liver Dis. 2017, 26, 29-35.

41. Prossnitz, E.R.; Barton, M. Estrogen biology: New insights into GPER function and clinical opportunities. Mol. Cell Endocrinol. 2014, 389, 71-83. [CrossRef] [PubMed]

42. Mendes-Oliveira, J.; Lopes Campos, F.; Videira, R.A.; Baltazar, G. GPER activation is effective in protecting against inflammation-induced nigral dopaminergic loss and motor function impairment. Brain Behav. Immun. 2017, 64, 296-307. [CrossRef] [PubMed]

43. Zhao, T.Z.; Ding, Q.; Hu, J.; He, S.M.; Shi, F.; Ma, L.T. GPER expressed on microglia mediates the anti-inflammatory effect of estradiol in ischemic stroke. Brain Behav. 2016, 6, e00449. [CrossRef] [PubMed]

(C) 2019 by the authors. Licensee MDPI, Basel, Switzerland. This article is an open access article distributed under the terms and conditions of the Creative Commons Attribution (CC BY) license (http://creativecommons.org/licenses/by/4.0/). 